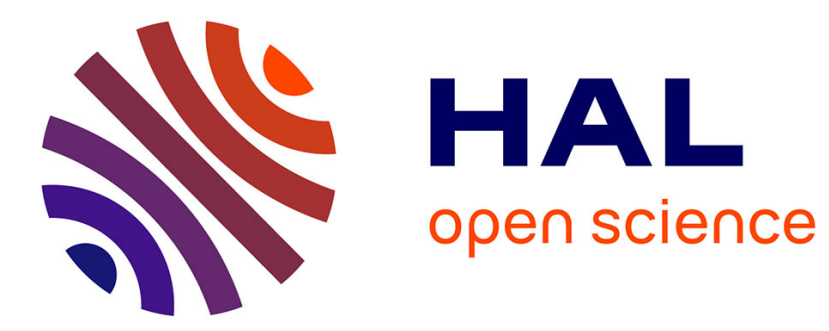

\title{
Optimizing product development in industry by alignment of the ISO/IEC 15288 Systems Engineering Standard and the PMBoK Guide
}

Rui Xue, Claude Baron, Philippe Esteban

\section{- To cite this version:}

Rui Xue, Claude Baron, Philippe Esteban. Optimizing product development in industry by alignment of the ISO/IEC 15288 Systems Engineering Standard and the PMBoK Guide. International Journal of Product Development, 2017, 22 (1), pp.65-80. 10.1504/IJPD.2017.085278 . hal-01887366

\section{HAL Id: hal-01887366 https://hal.science/hal-01887366}

Submitted on 26 Jun 2019

HAL is a multi-disciplinary open access archive for the deposit and dissemination of scientific research documents, whether they are published or not. The documents may come from teaching and research institutions in France or abroad, or from public or private research centers.
L'archive ouverte pluridisciplinaire HAL, est destinée au dépôt et à la diffusion de documents scientifiques de niveau recherche, publiés ou non, émanant des établissements d'enseignement et de recherche français ou étrangers, des laboratoires publics ou privés. 


\title{
Optimising product development in industry by alignment of the ISO/IEC 15288 systems engineering standard and the PMBoK guide
}

\author{
Rui Xue* and Claude Baron \\ LAAS-CNRS Laboratory, \\ 7 avenue du colonel Roche, F-31400 Toulouse, France \\ and \\ INSA, LAAS, \\ Université de Toulouse, \\ F-31400 Toulouse, France \\ Email: sherrysven@hotmail.com \\ Email: claude.baron@laas.fr \\ *Corresponding author

\section{Philippe Esteban} \\ LAAS-CNRS Laboratory, \\ 7 avenue du colonel Roche, F-31400 Toulouse, France \\ and \\ UPS, LAAS, \\ Université de Toulouse, \\ F-31400, Toulouse, France \\ Email: philippe.esteban@laas.fr
}

\begin{abstract}
As economic pressure continues to mount worldwide, closer cooperation is needed between people, companies and even countries. At the same time, the scale of projects is constantly rising. In order to ensure the success of large-scale projects, the way different teams cooperate is becoming increasingly important. Cooperation between systems engineering and project management is now key in this respect. On the other hand, it is widely recognised that the use of standards can improve the success ratio. Thus, integration using standards or guides from systems engineering and project management can help companies improve their competitiveness. A host of standards or guides have already been published in both domains. The purpose of this paper is to take the most frequently used standards or guides from systems engineering and project management, to compare them and build a bridge between them so as to provide a view shared by systems engineers and project managers enabling them to carry out their projects effectively.
\end{abstract}

Keyword: systems engineering; project management; standard; guide; process; alignment.

Reference to this paper should be made as follows: Xue, R., Baron, C. and Esteban, P. (2017) 'Optimising product development in industry by alignment of the ISO/IEC 15288 systems engineering standard and the PMBoK guide', Int. J. Product Development, Vol. 22, No. 1, pp.65-80. 
Biographical notes: Rui Xue is a Post-doc at LAAS-CNRS Laboratory (French National Centre for Sciences and Research). She received her PhD degree in Industrial Engineering in 2016 from National Institute of Applied Sciences (INSA) of the University of Toulouse (France). She received her ME degree in Computer Software and Theory in the year 2012 from Jilin University. Her $\mathrm{PhD}$ topic is about system engineering, project management, system modelling, and decision-making.

Claude Baron is Full Professor in Computer Sciences at the National Institute of Applied Sciences (INSA) of the University of Toulouse (France). She teaches systems engineering, system design and modelling, in master programs. Her current research is focusing on systems engineering, collaborative engineering and project management in engineering projects. She develops her research activities in the LAAS-CNRS Laboratory in Toulouse. She is the author of many international articles, (co)authored several books and received IEEE and INCOSE awards for her results.

Philippe Esteban is Associate Professor at the University of Toulouse. $\mathrm{He}$ conducts his research on System Engineering at the LAAS Laboratory of the CNRS (French National Centre for Sciences and Research). He is an expert in the domain of the design and verification of complex and hybrids systems. His predilection domain of application is embedded systems.

This paper is a revised and expanded version of a paper entitled 'Alignment of practices for an efficient management of Systems Engineering processes during the development of systems of systems' presented at the '2015 $3 r d$ World Conference on Complex Systems (WCCS)', Marrakech, Morocco, 23-25 November 2015.

\section{Introduction}

Systems Engineering (SE) and Project Management (PM) teams are obliged to work closely together when involved in large-scale projects (Clemens, 2012). As a result, there is a need for international companies to understand the standards or guides from both domains to better integrate the two sets of practices and enhance their chances of success. Although numerous SE and PM standards or guides have been published to help managers and engineers organise their processes better and improve the quality of their products or services, many projects still fail (Manyika et al., 2013). The Standish Group pointed out that only $16.2 \%$ of software projects are completed successfully, on time and on budget. Moreover, not all successful projects fully meet the original specifications. It is also worth noting that only $9 \%$ of projects in big companies were successful, while $31.1 \%$ of projects were cancelled before they were completed (The Standish Group, 2014)! According to a report drawn up by INCOSE UK, the effective use of systems engineering can save not only $10-20 \%$ of the project budget, but can also prevent half of all failures (INCOSE UK, 2009). It is well known that some failures are due to inconsistencies and a lack of consultation between the different SE and PM teams involved in the same project (Weingart and Jehn, 2000). The technical team will follow the project from a technical perspective, making use of engineering knowledge in an attempt to solve the technical problems, such as defining the customer's requirement and the product specifications, drawing up the Work Breakdown Structure (WBS) and so on, 
whereas the managerial team will follow the project globally, using certain performance indicators or Key Performance Indicators (KPIs) to evaluate the success of the project, such as earned value, labour costs and average time to delivery (Kerzner, 2004; Fernandez, 2008; Alwaer and Clements-Croome, 2010). So how to build a bridge between systems engineering and project management has become a critical problem for the entire project life cycle. For systems engineers and project managers to collaborate, they need to integrate their practices. The international systems engineering and project management standards and guides always provide the most widely used practices. The purpose of this paper is therefore to select one reference from among the most commonly used ones in Systems Engineering (the ISO/IEC 15288 standard) and one in Project Management (the PMBoK Guide) that describe the most useful practices for companies and then compare them, to assess whether a bridge could be built between the two references that would enable systems engineers and project managers to share a view and thus improve their chances of carrying out their projects successfully (Bock, 2005).

The motivation and evolution of research on this issue can be found in the next section. Brief introductions to the ISO/IEC 15288 standard and the PMBoK guide are also given in Section 3. In Section 4, the two references from the SE and PM domains are compared, while differences and similarities are highlighted by analysing first the general structure and then the content, and the degree to which they are compatible is described. The conclusion and prospects for further study are detailed in Section 5 .

\section{Integrating SE and PM: a real challenge!}

In a highly competitive environment, companies have to optimise their performance and practices to successfully implement their projects. The current issues concern the best way to simplify and speed up processes to better coordinate, control and manage these projects. Thus, there is a need not only to integrate systems engineering processes with the project management process (ISO, 2007), but also to help engineers and managers supervise and conduct their projects by implementing methods and support tools allowing them to make decisions jointly (Rachuri et al., 2005; Sage and Rouse, 2009; Kerzner, 2013). International organisations have devised many SE and PM standards or guides (e.g., ANSI/EIA 632, IEEE 1220 and the INCOSE HandBook and SEBoK for SE, or ISO 21500 for PM). However, there is as yet no single standard or guide providing for advanced cooperation between SE and PM, despite the fact that engineers and managers need to cooperate closely throughout the entire project development (Baron et al., 2015). We therefore need to compare and analyse the differences and similarities between SE and PM standards or guides and find ways to supplement them during project implementation.

The integration of SE and PM has long been considered; Mooz and Forsberg (1997), for example, proposed that SE and PM should be seen as an integrated process in 1997. And in order to improve the performance of SE and PM, new research has recently been carried out (Langley et al., 2011; Arnold, 2013; Xue et al., 2014c). In 2011, the International Council on Systems Engineering (INCOSE) and the Project Management Institute (PMI) recognised the importance of integrating SE with PM and agreed to tackle the question to help organisations reduce risks and improve returns on investment (Oehmen, 2011). Based on this consensus, the MIT conducted a survey which confirmed the need to overcome the barriers between systems engineers and project managers. They 
suggested four methods to enhance cooperation based on the analysis of several cases: using standards from both domains, formalising the definition of integration, developing integrated engineering program assessments and sharing responsibility for risk management, quality, life-cycle planning and external suppliers (Conforto et al., 2013). In May 2012, a guide entitled 'The Guide to Lean Enablers for Managing Engineering Programs' was published by the joint MIT-PMI-INCOSE Community of Practice on Lean in Program Management after a one-year research program on the integration of operations research, systems engineering and project management. It was intended to be used by managers and engineers to improve performance throughout their projects. The authors collected and synthesised data to provide the best guidance on how to implement projects more successfully (Oehmen et al., 2012).

This paper addresses the first suggestion made by MIT, to enhance cooperation by using a combination of standards from both domains. To do so, we reviewed the standards and guides from each domain (Xue et al., 2014b), compared them (Xue et al., 2014a) and conducted a survey on a panel of industrialists to identify the most commonly used standards and guides: in SE, the ISO/IEC 15288 standard is the one most often used, while in PM, the PMBoK is also the most widely followed guide internationally. In the next section, both references are considered.

\section{General introduction to the ISO/IEC 15288 standard and the PMBoK guide}

In this section, we first introduce the organisations in charge of developing standards or guides. We then briefly present the ISO/IEC 15288 standard and the PMBoK guide in terms of history, evolution and purpose.

With the increasing globalisation of markets, international standards have become critical to trading projects, ensuring that products and services meet internationally recognised levels of performance and safety. This encourages companies to use international standards or guides.

A standard is a document that provides requirements, specifications or guidelines to ensure that products, processes and services are fit for purpose (ISO, 2017). However, it does not give details on how to implement process requirements for engineering a system, nor does it specify the methods or tools a developer should use to implement process requirements. It facilitates communication between stakeholders, suppliers and buyers by giving them a common language (Martin, 1998). It can also be employed as a strategic tool by organisations or companies to reduce production costs. Products and services are safe, reliable and of good quality if they have been developed by companies following the standards. They also help companies access new markets and facilitate trade. Moreover, they produce other benefits, such as enhancing customer satisfaction, increasing sales and protecting the environment by reducing negative impacts (ISO, 2008).

Usually, a guide features more content than a standard. A standard does not contain the tools or a method that can be used, but the guide sometimes contains practices, tools and methods. For example, the PMBoK (A Guide to the Project Management Body of Knowledge) is a guide; in the first part, it provides some good practices for project management including tools and methods, and Annex A1 is the standard for project management. It details the processes and the process inputs and outputs. 
There are several organisations involved in the development of international standards. For example, one may cite ISO (International Organization for Standardization), IEEE (Institute of Electrical and Electronics Engineers), IEC (International Electrotechnical Commission) and PMI. IEC develops the international standards related to electro-technology and conformity assessment, whereas ISO has over 195,000 international standards covering nearly all other technical fields, a number of service sectors, management systems and conformity assessment (Bock, 2005). Companies therefore have to use a huge number of standards and guides as references. Among them are many popular standards, such as ISO 9000 for quality management, ISO 14000 for environmental management and ISO 31000 for risk management. PMI only focuses on drawing up the guides or standards related to management. There are so many international standards or guides that it is convenient to subdivide them into three categories (see Table 1).

Table 1 International standards or references by category

\begin{tabular}{lll}
\hline Category & Description & Popular standard or reference \\
\hline $\begin{array}{l}\text { Product standards or } \\
\text { guides }\end{array}$ & $\begin{array}{l}\text { Characteristics related to quality and } \\
\text { safety }\end{array}$ & $\begin{array}{l}\text { ISO 9001 Quality Management } \\
\text { Systems }\end{array}$ \\
\hline $\begin{array}{l}\text { Process standards or } \\
\text { guides }\end{array}$ & $\begin{array}{l}\text { Conditions under which products } \\
\text { and services are produced or } \\
\text { packaged }\end{array}$ & $\begin{array}{l}\text { ISO/IEC 15288 systems and } \\
\text { software engineering - system } \\
\text { life-cycle processes }\end{array}$ \\
\hline $\begin{array}{l}\text { Project management } \\
\text { standards or guides }\end{array}$ & $\begin{array}{l}\text { Helps organisations manage their } \\
\text { operations or projects }\end{array}$ & PMBoK \\
\hline
\end{tabular}

\subsection{ISO 15288}

The ISO/IEC 15288 is a Systems Engineering standard covering processes and life-cycle stages. Initial planning for the ISO/IEC 15288 standard started in 1994 when the need for a common Systems Engineering process framework appeared (ISO, 2008). ISO/IEC 15288 is the most famous and most used standard in systems engineering. Many other references, such as the INCOSE System Engineering Handbook, are based on the ISO/IEC 15288 .

This standard defines a set of processes that are applied to the development of products, systems or services, and the associated terminology. These processes can be applied at any level in the hierarchy of a system's structure. The ultimate goal is to achieve customer satisfaction (ISO, 2008). It defines the system life cycle as consisting of six stages: conception, development, production, utilisation, support and retirement. It can be applied concurrently, iteratively and recursively to a system and its elements. The systems considered in this international standard are man-made, created and utilised to provide products and/or services for the benefit of users and other stakeholders (ISO, 2008).

\section{$3.2 \quad P M B o K$}

The PMBoK was published in 1996 by the PMI; the first edition standardised some of the most common project management information and practices. The second edition was published in 2000. The third introduced some major changes in 2004. Four years later, the fourth edition was improved to be more complete. Finally, in 2013, the fifth edition added a whole new chapter about stakeholders (PMI, 2013). 
The PMBoK is a guide for project management; it provides a widely recognised standard and guidelines for project managers to run their projects effectively. Not only does it contain the standard that describes processes and their inputs and outputs, it also provides guidance about the tools and methods to be used as a resource in managing projects, while considering the overall approach and methodology to be followed (PMI, 2013). The PMBoK can be used before starting a project or at any stage to formalise it without overlooking key parameters. Depending on the project concerned, not all practices need to be applied systematically and some steps may be skipped.

\section{Comparison between ISO/IEC 15288 and PMBoK}

In this section, the two references will be compared at two levels. In Subsection 4.1, we first compare ISO/IEC 15288 and PMBoK by looking at how they are organised. We then analyse them according to the processes and activities involved. The comparisons of their focus along with a general comparison are given in Subsection 4.2.

\subsection{Analysis of the overall structure}

In this section, we show how both references are organised with the aim of comparing their overall structures. We then compare them at the process group level and at the processes and activities level. Lastly a conclusion is drawn from the comparisons at these two levels.

\subsubsection{Presentation of the organisation of ISO/IEC 15288 and PMBoK}

In this section, the overall organisation of IEC/ISO 15288 and the PMBoK are described in order to compare them in Subsections 4.1.2 and 4.1.3.

The ISO/IEC 15288 standard is broken down into three levels of processes. The first level features four process groups; the second level describes the 25 processes. Each process is presented in terms of purpose, outcomes and activities at the third level. Figure 1 shows the three levels of ISO/IEC 15288.

Figure 1 Structure of ISO/IEC 15288

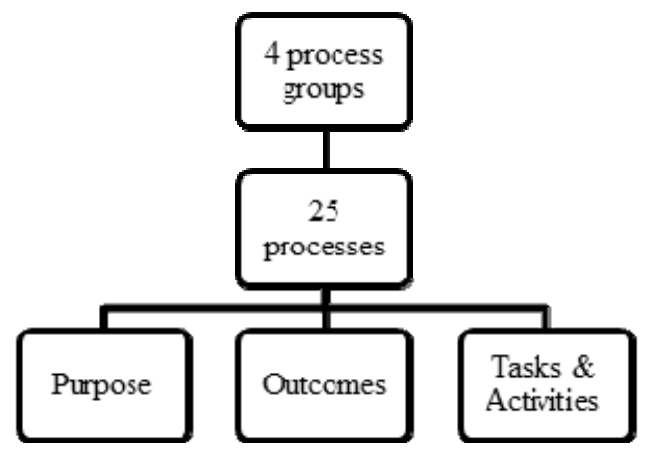

Each process is composed of three parts: purpose, outcomes and tasks and activities; the descriptions of the three parts are shown in Table 2. 
Table 2 Process component (ISO, 2008)

\begin{tabular}{ll}
\hline Part & Description \\
\hline Purpose & Describing the goals of performing the process \\
Outcomes & $\begin{array}{l}\text { Expressing the observable results expected from the successful } \\
\text { performance of the process }\end{array}$ \\
Tasks and Activities & $\begin{array}{l}\text { Explaining the requirements, recommendations, or permissible actions } \\
\text { intended to support the achievement of the outcomes } \\
\text { Describing the sets of cohesive tasks of a process }\end{array}$ \\
\hline
\end{tabular}

The PMBoK is also broken down into three levels; there are ten knowledge areas at the first level and five process groups at the second level; the relationships between the three levels of PMBoK are depicted in Figure 2.

Figure 2 The PMBoK structure

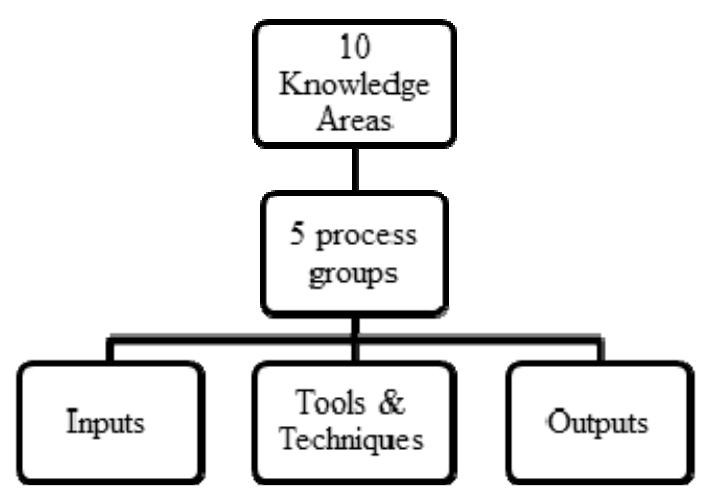

The ten knowledge areas are listed in Table 3.

Table 3 Ten knowledge areas of PMBoK (PMI, 2013)

\begin{tabular}{ll}
\hline Area & Description \\
\hline Integration & $\begin{array}{l}\text { Identifying and coordinating the various processes and activities } \\
\text { Making resource allocations, trade-offs between objectives } \\
\text { Managing interdependencies }\end{array}$ \\
\hline Scope & $\begin{array}{l}\text { Ensuring that the project includes all the tasks required to complete the } \\
\text { project successfully } \\
\text { Defining and controlling what is and is not included in the project }\end{array}$ \\
\hline Time & Managing the completion of the project in the predicted time \\
\hline Cost & $\begin{array}{l}\text { Budgeting, financing, funding, managing and controlling costs to } \\
\text { complete the project within the approved budget }\end{array}$ \\
\hline Quality & $\begin{array}{l}\text { Determining quality policies, objectives, and responsibilities } \\
\text { Ensuring that the project requirements, including product requirements, } \\
\text { are met and validated }\end{array}$ \\
\hline Human Resource & $\begin{array}{l}\text { Organising, managing and leading the project team } \\
\text { Assigning roles and responsibilities to people }\end{array}$ \\
\hline
\end{tabular}


Table 3 Ten knowledge areas of PMBoK (PMI, 2013) (continued)

\begin{tabular}{ll}
\hline Area & Description \\
\hline Communications & $\begin{array}{l}\text { Ensuring distribution, storage, management, control, monitoring, and } \\
\text { disposition of project information }\end{array}$ \\
Risk & $\begin{array}{l}\text { Conducting risk management planning, identification and analysis } \\
\text { Controlling risk on a project }\end{array}$ \\
Procurement & Purchasing or acquiring products, services or results \\
& Managing contracts with suppliers or customers \\
Stakeholder & Identifying the people impacting or being impacted by the project \\
& Analysing stakeholder expectations \\
& Developing appropriate management strategies \\
\hline
\end{tabular}

A knowledge area represents a complete set of concepts, terms, and activities that make up a professional field, project management field, or area of specialisation. There are five process groups that compose each of the ten knowledge areas (PMI, 2013).

Table 4 Five process groups (PMI, 2013)

\begin{tabular}{|c|c|}
\hline Group & Description \\
\hline Initiating & $\begin{array}{l}\text { Defining a new project or a new phase of an existing project by } \\
\text { obtaining authorisation to start it }\end{array}$ \\
\hline Planning & $\begin{array}{l}\text { Establishing the scope of the project and defining the objectives and the } \\
\text { course of action required to reach the objectives }\end{array}$ \\
\hline Executing & $\begin{array}{l}\text { Completing the work defined in the project management and planning } \\
\text { to satisfy the project specifications }\end{array}$ \\
\hline $\begin{array}{l}\text { Monitoring \& } \\
\text { Controlling }\end{array}$ & $\begin{array}{l}\text { Reviewing and regulating the progress of the project; identifying any } \\
\text { areas in which changes to the plan have to be made and initiating the } \\
\text { corresponding changes }\end{array}$ \\
\hline Closing & $\begin{array}{l}\text { Finalising all activities across all Process Groups to formally close the } \\
\text { project }\end{array}$ \\
\hline
\end{tabular}

These five Process Groups are clearly interdependent and are typically performed in each project and interact with one another. They are independent of application areas. Each process is characterised by its inputs, the tools \& techniques that can be applied and the resulting outputs (PMI, 2013).

\subsubsection{Comparison between ISO/IEC 15288 and PMBoK regarding a breakdown of the first level of their respective structures}

In this section, ISO/IEC 15288 and PMBoK are compared regarding the first-level breakdown (processes and knowledge areas, respectively).

How the 25 processes of ISO/IEC 15288 and the ten knowledge areas of the PMBoK are related will be shown in Figure 3. This comparison is based on ISO/IEC 15288; Figure 3 therefore highlights those parts of the PMBoK covered or not covered by the said standard. If a knowledge area is shown with a dashed border, it means that this knowledge area is only partially covered by ISO/IEC 15288. If it is shown with a solid border, it means that the whole knowledge area can be found in the said standard. 
Figure 3 Comparison between ISO/IEC 15288 and PMBoK at the first level

\begin{tabular}{|c|c|c|c|c|}
\hline Agreement Processes & Project Processes & Technical Processes & \multirow{2}{*}{ Integration } & \multirow[b]{2}{*}{ Scope } \\
\hline Acquisition Process & \multirow{3}{*}{$\begin{array}{l}\text { Project Planning } \\
\text { Process }\end{array}$} & \multirow{2}{*}{$\begin{array}{l}\text { Stakeholder Requirement } \\
\text { Definition Process }\end{array}$} & & \\
\hline Supply Process & & & & \\
\hline Organizational & & $\begin{array}{c}\text { Requirement Analysis } \\
\text { Process }\end{array}$ & \multirow{2}{*}{ Time } & \multirow{2}{*}{ Cost } \\
\hline $\begin{array}{l}\text { Project-Enabling } \\
\text { Processes }\end{array}$ & \multirow{2}{*}{$\begin{array}{l}\text { Decision Management } \\
\text { Process }\end{array}$} & $\begin{array}{l}\text { Architecture Design } \\
\text { Process }\end{array}$ & & \\
\hline Life Cycle Model & & Implementation Process & & \\
\hline Management Process & \multirow{2}{*}{$\begin{array}{l}\text { Risk Management } \\
\text { Process }\end{array}$} & & \multirow[t]{2}{*}{ Quality } & \multirow[t]{2}{*}{ Human resource } \\
\hline Infrastructure & & Integration Process & & \\
\hline Management Process & \multirow{2}{*}{$\begin{array}{c}\text { Configuration } \\
\text { Management Process }\end{array}$} & Verification Process & & \\
\hline $\begin{array}{c}\text { Project Portfolio } \\
\text { Management Process }\end{array}$ & & Transition Process & \multirow[t]{3}{*}{ Communication } & \multirow[t]{2}{*}{ Risk } \\
\hline \multirow{2}{*}{$\begin{array}{c}\text { Human Resource } \\
\text { Management Process }\end{array}$} & \multirow{2}{*}{$\begin{array}{c}\text { Information } \\
\text { Management Process }\end{array}$} & Validation Process & & \\
\hline & & Operation Process & & \\
\hline \multirow{2}{*}{$\begin{array}{l}\text { Quality Management } \\
\text { Process }\end{array}$} & \multirow[t]{2}{*}{ Measurement Process } & Maintenance Process & \multirow[t]{2}{*}{ Procurement } & \multirow[t]{2}{*}{ Stakeholder } \\
\hline & & Disposal Process & & \\
\hline
\end{tabular}

The following table matches the processes of ISO/IEC 15288 with the knowledge areas of PMBoK.

Table 5 Matching items between ISO/IEC 15288 and PMBoK

\begin{tabular}{lc}
\hline $\begin{array}{l}\text { ISO/IEC 15288: 25 processes } \\
\text { (14 different) }\end{array}$ & PMBoK: ten knowledge areas \\
\hline Decision Management Process & Integration \\
Project Planning Process & \\
Project Assessment and Control Process & \\
Configuration Management Process & Scope \\
\hline Stakeholder Requirements Definition Process & \\
Requirement Analysis Process & \\
Project Planning Process & Time \\
Project Assessment and Control Process & \\
Configuration Management Process & \\
\hline Project Planning Process & Cost \\
Project Assessment and Control Process & \\
Configuration Management Process & \\
\hline Project Portfolio Management Process & \\
Project Planning Process & \\
Project Assessment and Control Process & \\
Configuration Management Process &
\end{tabular}


Table 5 Matching items between ISO/IEC 15288 and PMBoK (continued)

\begin{tabular}{lc}
\hline $\begin{array}{l}\text { ISO/IEC 15288: 25 processes } \\
\text { (14 different) }\end{array}$ & PMBoK: ten knowledge areas \\
\hline Quality Management Process & \\
Project Planning Process & Human Resource \\
$\begin{array}{l}\text { Project Assessment and Control Process } \\
\text { Configuration Management Process }\end{array}$ & \\
\hline Human Resource Management Process & Communications \\
Configuration Management Process & \\
\hline $\begin{array}{l}\text { Information Management Process } \\
\text { Measurement Process }\end{array}$ & \\
Configuration Management Process & Risk \\
\hline $\begin{array}{l}\text { Risk Management Process } \\
\text { Configuration Management Process }\end{array}$ & Procurement \\
\hline $\begin{array}{l}\text { Acquisition Process } \\
\text { Supply Process }\end{array}$ & Stakeholder \\
\hline Configuration Management Process & \\
\hline Decision Management Process & Configuration Management Process
\end{tabular}

As shown in Table 5, the 'Project Planning' and 'Project Assessment and Control' processes match the following five knowledge areas: Integration, Scope, Time, Cost and Quality. The knowledge areas 'Stakeholder' and 'Integration' are only partially covered by the 'Decision Management' process. Consequently, some parts of these two knowledge areas are not covered by ISO/IEC 15288. As explained in the previous section, the PMBoK is structured such that each knowledge area is made up of five processes and each process also produces outputs. Some of these outputs (especially the 'project document updates') deal with configuration management. Thus, the ten knowledge areas cover the 'Configuration Management' process.

\subsubsection{Comparison between ISO/IEC 15288 and PMBoK with respect to second-level breakdown}

In this section, the relationships between the tasks and activities of ISO/IEC 15288 and the five processes of the PMBoK are presented.

Table 6 Relationship between ISO/IEC 15288 and the PMBoK

\begin{tabular}{ll}
\hline ISO/IEC 15288: tasks and activities & PMBoK: five processes \\
\hline Prepare, Initiate, Identify, Establish, Define, Elicit & Initiating \\
Advertise, Develop, Plan, Manage & Planning \\
Execute, Evaluate, Acquire, Activate, Analyse & Executing \\
Monitor, Deliver, Assess, Provide, Control, Treat & Monitoring and Controlling \\
Accept, Close, Improve, Maintain, Perform, & Closing \\
Support, Finalise & \\
\hline
\end{tabular}


Words shown in bold are those used most often in ISO/IEC 15288. In PMBoK, there are mostly five processes but it can also vary between four and six. In ISO/IEC 15288, there may be between two and six tasks and activities but mostly three. Figure 4 shows the process relationship between ISO/IEC 15288 and PMBoK.

Figure 4 Process relationship between ISO/IEC 15288 and PMBoK

ISO/IEC 15288

Human Resource

Management Process

4 Tasks \&

Activities

\section{PMBoK}

Project Human

Resource Management

4 Processes
1. Identify skills

2. Develop skills

3. Acquire \& provide skills

4. Perform knowledge management
1. Plan human resource

2. Acquire project team

3. Develop project team

4. Management team

\subsubsection{Conclusion on the comparison between ISO/IEC 15288 and PMBoK}

As already been presented and compared in the organisation of the two references, levels of breakdown can be highlighted (see Figures 1 and 2). We found that the general structures are compatible, which is the first similarity between the two references. With respect to these figures, both references are broken down into three levels. However, these levels do not refer to the same thing, so a linear match between levels cannot be achieved at the same degree of breakdown. Nonetheless, by going deeper into each level, another more sophisticated match can be found. This is shown below in Figure 5.

Figure 5 Matches between the three levels of the two references

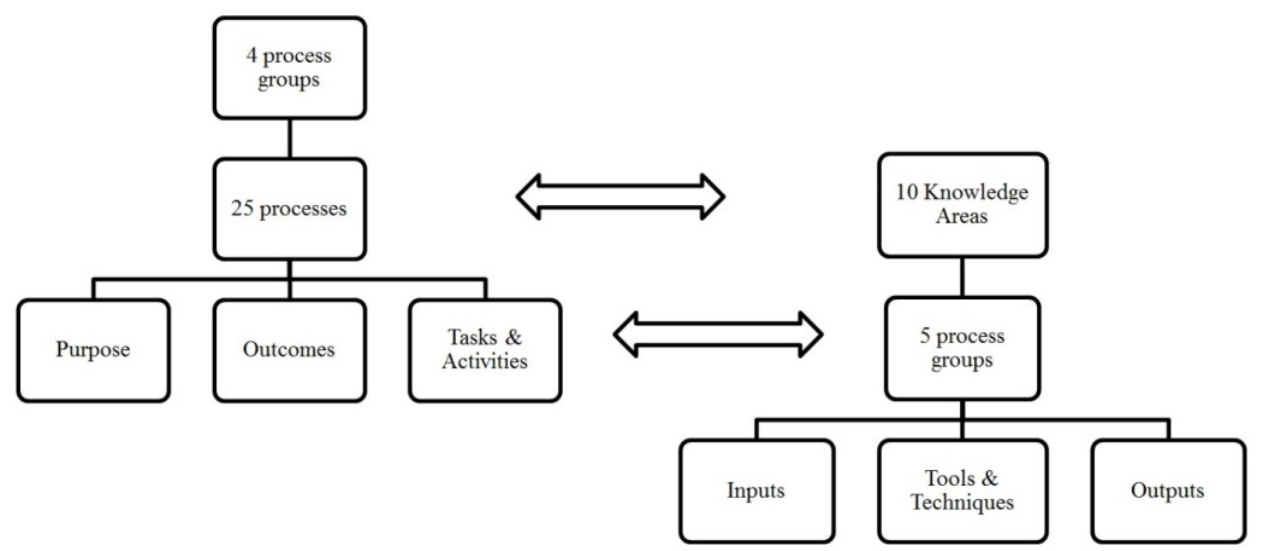


In Figure 5, it can be seen that it is only necessary to move downward one step in the breakdown of the PMBoK to get a match. The 25 processes of ISO/IEC 15288 can now be compared to the ten knowledge areas of the PMBoK, even if the numbers of processes and knowledge areas are not the same. The five process groups of the PMBoK are similar to the tasks and activities of ISO/IEC 15288.

\subsection{Content analysis}

After comparing both organisations it is worthwhile having a look at the contents of both references. Our analysis of the content of each reference revealed some interesting features that will be detailed in this section. This will conclude the analysis of the reference in the scope of this paper.

\subsubsection{Focus on the different systems in the standard and guide}

After analysing the systems covered by the two references, it becomes apparent that the standard and guide each focus on a different type of system. Indeed, the system addressed by PMBoK's is a project, whereas that addressed by ISO/IEC 15288 is a product or service. This is the case in each knowledge area and in each process.

For example, 'Risk Management Process' in ISO/IEC 15288 deals with a product or service as shown in the following definition: 'The Risk Management process is a continuous process for systematically addressing risk throughout the life cycle of a system, product or service'. Likewise, 'Project Risk Management' in the PMBoK deals with a project as shown in the following definition: 'Project Risk Management includes the processes of conducting risk management planning, identification, analysis, response planning, and monitoring and controlling risk on a project'.

Nevertheless, the approaches, processes and steps remain the same. For example, the tasks and activities of the process 'Risk Management Process' (ISO/IEC 15288) match every process of the knowledge area 'Project Risk Management', as shown in Table 7.

Table 7 Focus on different systems in ISO/IEC 15288 and PMBoK

\begin{tabular}{ll}
\hline Risk Management Process (ISO/IEC 15288) & Project Risk Management (PMBoK) \\
\hline Tasks and activities: & Five processes: \\
Plan risk management & 1. Plan risk management \\
Manage the risk profile & 2. Identify risks \\
Analyse risks & 3. Perform qualitative risk analysis \\
& 4. Perform quantitative risk analysis \\
Treat risks & 5. Plan risk responses \\
Monitor risks & 6. Control risks \\
Evaluate the risk management process & \\
\hline
\end{tabular}

\subsubsection{Chronologically versus concurrently}

When implementing the processes, an important difference is whether they can be implemented simultaneously or must be applied chronologically.

For the PMBoK, the ten knowledge areas can be executed concurrently. Indeed, each knowledge area is an important project management field, and information about cost or 
time must always be available. All the knowledge areas will not begin and end at the same time but they are all independent. Conversely, the five processes of the ISO/IEC 15288 standard must be executed one after the other.

Figure 6 Major time considerations for ISO/IEC 15288 and PMBoK

ISO/IEC 15288

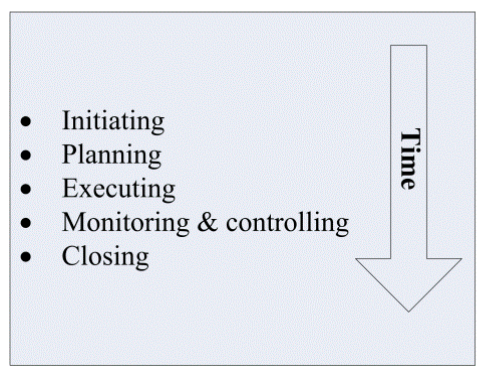

PMBoK

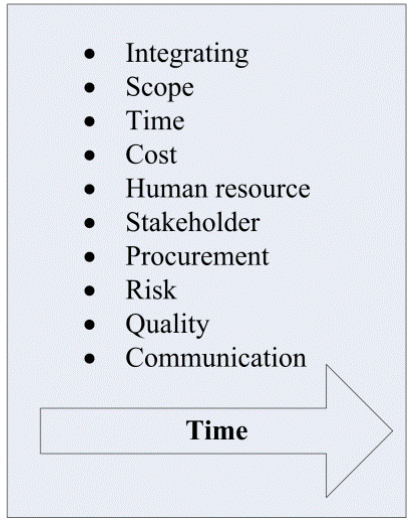

For ISO/IEC 15288, the four process groups: 'Agreement processes', 'Technical processes', 'Project processes' and 'Organisational-project-enabling processes' can be executed concurrently. Some of the processes can run simultaneously, while the others must be executed in a chronological order. For example, the two processes 'Acquisition Process' and 'Supply Process' (pertaining to the 'Agreement Processes') can run simultaneously. However, almost all the processes belonging to the 'Technical processes' must be executed one after the other. Finally, all 'Tasks and Activities' in each processes have to be executed in chronological order.

Figure 7 Some time considerations for ISO/IEC 15288 and PMBoK

ISO/IEC 15288

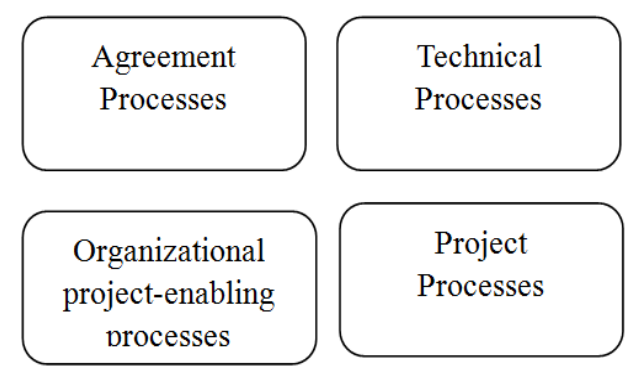

\section{PMBoK}

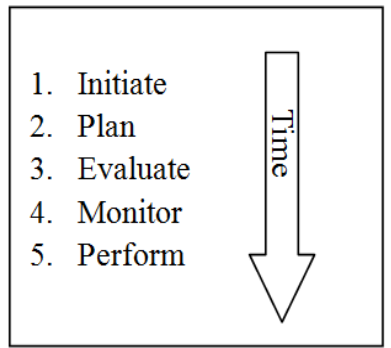

\subsubsection{General comparison}

The first general remark that can be made is that the degree of explanation differs between the standard and the guide. The PMBoK is more detailed than ISO/IEC 15288. 
This can be easily verified by the number of pages. ISO/IEC 15288 is 84 pages long, whereas PMBoK is 616 pages long. Moreover, the manner in which both documents are structured also accounts for these differences. In ISO/IEC 15288, there are only separate chapters for the four main categories of processes and one small section for each process; whereas in PMBoK, one chapter is devoted to each knowledge area and a small portion of each chapter is devoted to each process.

Secondly, as stated above in Subsection 3.2, in the structure of the five processes of PMBoK, there are presentations of the tools and methods corresponding to the processes. It is indeed useful to fully understand the tools or methods for implementing the processes effectively. However, the ISO/IEC 15288 standard does not mention any corresponding tools and methods at all. Thirdly, it is important to know whether the words used in the standard and guide convey the same meaning. In fact, after reviewing the words used in both references, it appears that there are no real differences on the technical side, for example, the words 'specification' and 'risk' has the same meaning in both references. The only noteworthy difference concerns the word 'system'. ISO/IEC 15288 focuses on technical systems, whereas PMBoK considers each project to be a 'system'. This may account for the communication difficulties observed between stakeholders.

\section{Conclusion}

To develop a project quickly and effectively and to optimise operation management, it is better to be familiar with the references from both the Systems Engineering and Project Management domains and integrate them during project implementation. For this paper, a comprehensive study of the PMBoK and ISO/IEC 15288 was carried out. Firstly, we introduced the two references briefly. This introduction can help systems engineers and project managers understand both references more quickly and have a global view of systems engineering and project management standards and guides. We then compared them to highlight differences and similarities at different levels. We first compared them based on the general structures of both references, we analysed ISO/IEC 15288 and PMBoK in terms of the processes and activities, and we also identified those parts of the reference covered by one or the other. In the second part, we analysed both contents to study their points of view. We concluded that the type of systems on which the ISO/IEC 15288 reference focuses is a product or service, whereas the PMBoK focuses on a project. ISO/IEC 15288 focuses essentially on technical aspects and only a few projectrelated concepts are treated. Conversely, PMBoK focuses only on the project aspect. In addition, each reference has its own organisational structure but they are consistent, complementary and follow the same approach. When implementing the project management processes of ISO/IEC 15288, the tools or methods from PMBoK can be used as reference. These two references can also be employed differently. We can use the technical processes from the ISO/IEC 15288 standard to complete the PMBoK. For example, when the technical process is needed during implementation of the project, we could first use the ISO/IEC 15288 standard as reference, and then the Project Management processes of the PMBoK. This paper can provide project managers and systems engineers with an approach for comparing the references from the SE and PM domains. Following this methodology can make the comparison of references from different domains much easier and help project managers reduce their time and cost by aligning the processes from the SE and PM references during the project. 
In order to complete the ultimate goal of integrating methods and tools from System Engineering and Project Management as a way of supporting product development, one may align the two references to facilitate the management of the technical project. However, how best to combine these references remains an interesting area to explore.

\section{References}

Alwaer, H. and Clements-Croome, D.J. (2010) 'Key performance indicators (KPIs) and priority setting in using the multi-attribute approach for assessing sustainable intelligent buildings', Building and Environment, Vol. 45, No. 4, pp.799-807.

Arnold, E.P. (2013) 'Call for an effective alignment of program management and systems engineering risk management practices', INCOSE International Symposium, Vol. 23, No. 1, pp.677-693.

Baron, C., Esteban, P., Xue, R., Esteve, D. and Malbert, M. (2015) 'A method and tool to support the management of systems engineering projects', Technology Innovation Management Review, Vol. 5, No. 3, pp.18-28.

Bock, C. (2005) 'Systems engineering in the product lifecycle', International Journal of Product Development, Vol. 2, Nos. 1/2, pp.123-137.

Clemens, N. (2012) Systems Engineering (SE) \& Project Management. Available online at: https://fr.scribd.com/document/123463097/Systems-Engineering-and-Project-Management (accessed on 23 January 2017).

Conforto, E., Rossi, M., Rebentisch, E., Oehmen, J. and Pacenza, M. (2013) Survey Report: Improving Integration of Program Management and Systems Engineering, MIT Consortium for Engineering Program Excellence, Cambridge, MA.

Fernandez, D.J. (2008) 'Agile project management - agilism versus traditional approaches', Journal of Computer Information Systems, Vol. 49, No. 2, pp.10-17.

INCOSE UK (2009) Why Do Systems Engineering? Manage Complexity. Reduce Your Risk. Available online at: http://www.incose.org/docs/default-source/default-document-library/twgse101-v11-2014-01-20.pdf?sfvrsn=4 (accessed on 23 January 2017).

ISO (International Organization for Standardization) (2007) ISO/IEC 26702: Systems Engineering - Application and Management of the Systems Engineering Process, ISO, Geneva.

ISO (2008) ISO/IEC/IEEE Systems and Software Engineering - System Life Cycle PROCESSES, IEEE, Geneva.

ISO (2017) What is a Standard? Available online at: http://www.iso.org/iso/home/standards.htm (accessed on 23 January 2017).

Kerzner, H. (2004) Advanced Project Management: Best Practices on Implementation, John Wiley \& Sons, Hoboken, NJ.

Kerzner, H. (2013) Project Management: A Systems Approach to Planning, Scheduling, and Controlling, John Wiley \& Sons, Hoboken, NJ.

Langley, M., Robitaille, S. and Thomas, J. (2011) 'Toward a new mindset: bridging the gap between program management and systems engineering', INSIGHT, Vol. 14, No. 3, pp.4-8.

Manyika, J., Chui, M., Bughin, J., Dobbs, R., Bisson, P. and Marrs, A. (2013) Disruptive Technologies: Advances that will Transform Life, Business, and the Global Economy, Vol. 180, McKinsey Global Institute, San Francisco, CA.

Martin, J.N. (1998) 'Evolution of EIA 632 from an interim standard to a full standard', Proceedings of INCOSE 1998 Symposium, Vancouver, Canada.

Mooz, H. and Forsberg, K. (1997) 'Visualizing system engineering and project management as an integrated process', INCOSE International Symposium, Vol. 7, No. 1, pp.573-580. 
Oehmen, J. (2011) 'Advances in the integration of program management and systems engineering: progress of the INCOSE-PMI-LAI community of practice on lean principles in program management', INSIGHT, Vol. 14, No. 4, pp.44-44.

Oehmen, J., Oppenheim, B.W., Secor, D., Norman, E., Rebentisch, E., Sopko, J.A., Steuber, M., Dove, R., Moghaddam, K., McNeal, S. and Bowie, M. (2012) The Guide to Lean Enablers for Managing Engineering Programs, Joint MIT-PMI-INCOSE Community of Practice on Lean in Program Management, Cambridge, MA.

PMI (Project Management Institute) (2013) A Guide to the Project Management Body of Knowledge: PMBOK V5, PMI, Philadelphia, PA.

Rachuri, S., Baysal, M., Roy, U., Foufou, S., Bock, C., Fenves, S., Subrahmanian, E., Lyons, K. and Sriram, R. (2005) 'Information models for product representation: core and assembly models', International Journal of Product Development, Vol. 2, No. 3, pp.207-235.

Sage, A.P. and Rouse, W.B. (2009) Handbook of Systems Engineering and Management, John Wiley \& Sons, Hoboken, NJ.

The Standish Group (2014) The Standish Group CHAOS Report, Project Smart. Available online at: https://www.projectsmart.co.uk/white-papers/chaos-report.pdf

Weingart, L.R. and Jehn, K.A. (2000) 'Manage intra-team conflict through collaboration', in Locke, E.A. (Ed.): Handbook of Principles of Organization Behavior, John Wiley \& Sons, West Sussex, pp.226-238.

Xue, R., Baron, C. and Esteban, P. (2014a) 'How compatible systems engineering and project management standards are considering the way they manage systems engineering processes?', 15th Congrès des Doctorants EDSYS (École Doctorale Systèmes), 22-23 May, Toulouse, France.

Xue, R., Baron, C., Esteban, P., Esteve, D. and Malbert, M. (2014b) 'Towards the success of design projects by the alignment of processes in collaborative engineering', Proceedings of the Joint Conference on Mechanical, Design Engineering \& Advanced Manufacturing, 18-20 June, Toulouse, France.

Xue, R., Baron, C., Esteban, P. and Prun, D. (2014c) 'Integrating systems engineering with project management: a current challenge', INCOSE 2014 International Symposium. Proceeding of the INCOSE 2014 International Symposium, 30 June-3 July 3, Las Vegas, NV, USA, pp.693-704. 